\title{
Medical Applications of Space Light-Emitting Diode Technology — Space Station and Beyond
}

\author{
Harry T. Whelan, M.D. ${ }^{\text {la }}$, John M. Houle, B.S. ${ }^{\text {la }}$, \\ Deborah L. Donohoe, A.S.,L.A.T.G.' ${ }^{\text {,a }}$, Dawn M. Bajic, B.S.' , \\ Meic H. Schmidt, M.D. Is, Kenneth W. Reichert, 11, M.D." , \\ George T. Weyenberg, R.N. ${ }^{\text {la }}$, David L. Larson, M.D. ${ }^{\text {b }}$, Glenn A. Meyer, M.D. ${ }^{\text {a }}$ \\ James A. Caviness, M.D ${ }^{2}, 2$

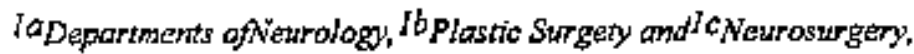 \\ Medicol College of Wisconsin, Milwaykes, WI 53226 , (474) 456-4090 \\ ${ }^{2}$ Noval Hospital Great Lakes, Great Lohes, IL 6008s, (847) 688-7400
}

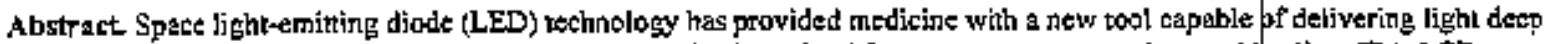
inco tissues of the boty. at wavelengths which are biologjeply optimal for cancer treatment add wound healing. This LED technology has already flow on Space Shuttle missions, and shows promize for uound healng applictuons of benefít to Spoce Station astronauts.

\section{PHOTODYNAMIC TEERAPY}

Photodynamic therapy (PDD) is a cancer treatment modalicy that recently has been applied as adjuvan: therapy for brain cumors. PDT consists of intravenously injecting a photosensitizer, which preferemially accumulates in tumor sells, into a palient and then activating the photosensitizer with a light gource. This tesults in iree radical generation followed by eell death. The developnent of more effective light soutets for PDT of btain tunors has beeri facilitated by applications of spae light-tmitting diode aray technology; thus permitting depper tumor penetration of light and use of berter photosengiliztrs. Lutetium Texaphyrin (Lulex) is a uew, second gen eration photosensitizer that can potentially irnprowe PDT for brain tumors. Lutex has a major absoption peak at $730 \mathrm{hm}$, which gives it two distinct advantages. First, longer wavelengths of light penetrate brain tissue exsily so that arger tumors could be treated, and sesond, the major absorption peak means that more of the drug is activated upon exposure to light. Tumoricidal effects of Lutex have been swdied in vitso using canine gliona and human gligblastoma cell culdures. Using light eminting diodes (LED) with a peak emission of $728 \mathrm{~nm}$ as a light source, a grealer than 50 percent cell kill wras measured in both cell lires by tumor DNA syothesis reduction. The effectivemess of Lutex against tumor cells in witso thus established, we have taken the first step toward detentining fis effectiveness in vivo by performing experiments to deten-nine the largest dose of both Lutex and light that can be admisistered to dogs before toxicity is seen i.e. the maximum tolerated dose (MTD). Using this dose allows us to pffect maximunis tumor cell destrucoion during in wivo studies. Baged upon the MTD of Lutex in dogs, human tials a de now anticipated.

\section{WOUND HEALING}

Wounds heal less effectively in space than here or edth. Improved wound healing may have multiple applications which benefiting civilian medieal care, military situations and long-term spaes flight. Laset light and hyperparic oxygen have beert wicely acclaimed to spetd wound healing in ischemis, hypoxic wounds. Lasers prowide low energy stimulation of tissues which resulss in increased cellular ectivity during wound healing. Some of these activities include increased fibroblast proliferation, growth fattor synthesis, collagen prodution and angiogenesis. Hyperbaric oxyenen therapy has also been shown to beneficially affect these proeesses.

CP458, Space Technolagy and Applications Intemanional Foram- 1999 edited by Mohamed S. El-Gank 
Lasers, however, have some inherest characterjstics which make their use in a clioical sertist problematic, including limintions in wavelength oupbitities and bean widh. The combined wavelengths of tighe optimal for wound healing carnot be effoienty produced, and the size of wounds which may be treated by lastro is linaterd. Lighremining diodes (LEDs) offer an effective alternative to lasers (Table 1, Figure 1). These diodes can be made to produce multiple wavelengths, and can be arranged in large, flat arrays allowing treatment of large wounds.

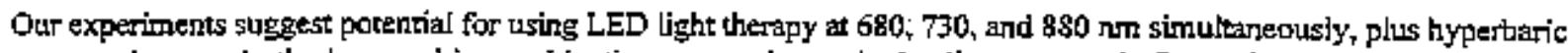
oxystu theray, both alone and to combination, to accelerate the hoaling prosess in Space Starion missions, where prolomged exposure to micrograwity may otherwise retard healing.

TABLE 1. Output Spocitroarions for Wound Trealment LED Amay.

\begin{tabular}{|c|c|c|c|}
\hline & Min & Typ & Max \\
\hline \multicolumn{4}{|l|}{ Surfaee Energy ('670n:m) } \\
\hline Power Culput ( $\left.\mathrm{m} \mathrm{W}_{\mathrm{cm}} \mathrm{m}^{2}\right)$ & 25 & 29 & 34 \\
\hline Quaram (1) & 1800 & 2100 & 2400 \\
\hline \multicolumn{4}{|l|}{ Surface Enetgy (735nm) } \\
\hline Power Output (mW/em²) & 25 & 29 & 34 \\
\hline
\end{tabular}
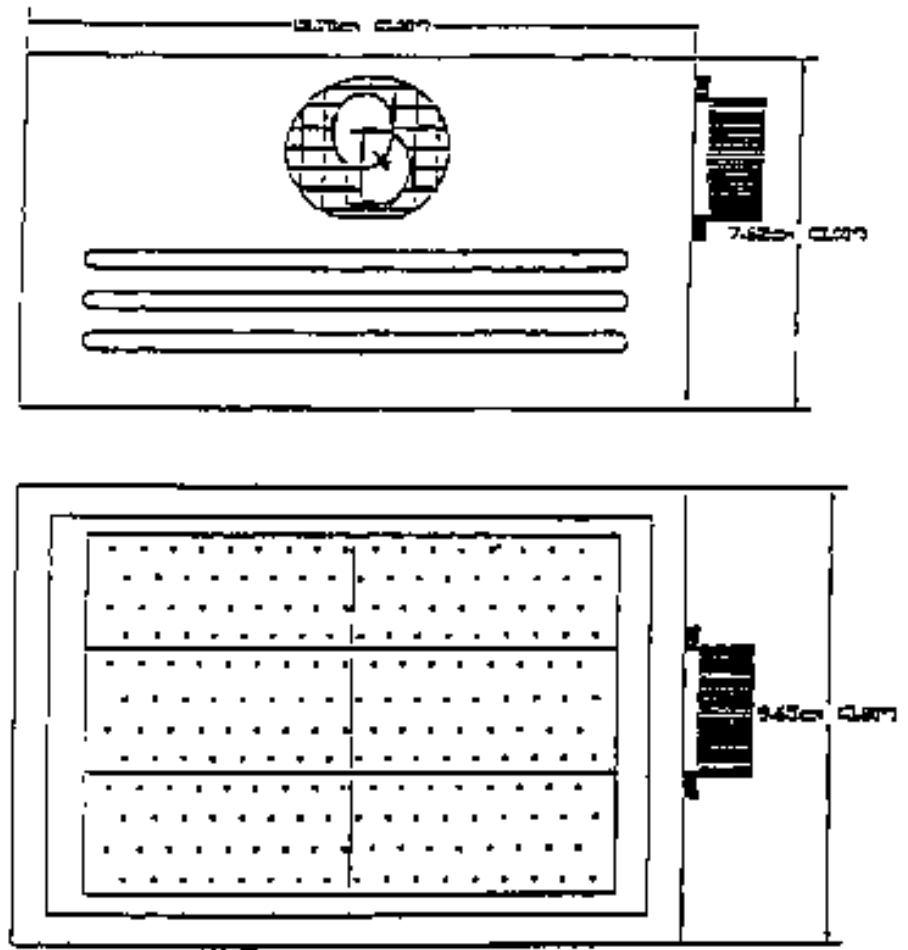

FIGURE 1. LED Arry for Treating Wounds ax $670 \mathrm{~mm}$ and $735 \mathrm{~nm}$. 


\section{PART I - PHOTODYNAMTC THERAPY}

\section{Introduction}

Photosensitizers are light stensitive molecules that upon activation writh light can canse photodynamic damage to cells in which they lotelize (Henderson, 1992). For photodynamic therapy of solid numors, in particular brain tumors a photosensinizer should selectively localize in malignant cells versus nomal brain and be activated by light that can penetrate deeply into solid tissue. ln general, light penetration in the brain and other solid tissues increases for light with longer twateliengtis (Egger, 1993). Therefore, in onder to effectively trat solid tumors one must have a phorosensitizer that absorbs light preferentially at long wayelengths.

Tradifionally rwo similar photosensitizers, namely Hematoporphytin and its more purified fom Photofrino have betn the most widely applied in the adjuwant treatuent of brain tunors (Kostrom, 1996; Multer, 1995; Origitano, 1994; Popovic, 1995). Both of these photosensitizers bave major absorption peaks in the short wavelengths of light and a smaller peak in the near infrared specturn at $630 \mathrm{~nm}$. At that wavelengh, light penetration is limited and deeper photosensitized anncr cells are not eliminated because of che lack of light activation (Kosưom, 1996). Therefore, one way to improve the efficacy of PDT of solid tumars is to use photosensitizers that can absorb an longer travelengths of light.

Red laser light is frequently prodtued usine an argon ion or KTP/YAG laser bearn that is converted by a dye module, usually to $630 \mathrm{~nm}$. For longer wavelengths of light improved tachnology is required Laser conversion to near-inffared wavelengths is inherently costly and ineffieient, but allows for light to be delivered by fiberoptics. For non-fiberoptic delivery of light, other light sourits could be a useful altenative.

Lieht-emitting diodes (LED) are one such light soure that may prove to be an effective alterative to lasers for PDT. LED's have besen frequently used to amit low pow/er, broad spectum light of 25.30 nn banduridths for photosynthesis restarch in plans. LED lamps traditionally consist of an array of semiconducting LED chips. In recent years. improwements in sersiconducter technology have substantially increased the light output of LED chips. A novel type of LED chip is based on the semiconductor Aluminum Gallium Arsenide (A 1GaAs). These LED chips tan be mamififachured to emit light with a peak wavelength between $630 \mathrm{~nm}$ and $940 \mathrm{~nm}$. This range of wavelengths overlaps with the absorption spectrum of photosensibzers used for PDT of brain tumars.

Lutetium Texaphyrin (La-Tex) is a new photosensitizer that has strong light absorption from 730 to 770 nin with absorption peak at 732 am (Young, 1996). In addition, Lu-Tex is water-soluble and has a High, lonts-liwed quanturn yiveld for triplet states that can produce cytotoxic singlet oxygen.

The aim of this study was to evaluate the potential effects of Lu-Tex in combinarion with light-emitting diode bulloon applicator on nomal brain tissue and to iovestigate cytotoxicity in glioma cell lines.

\section{Materials and Methods}

In vitro and in wivo experinents were condueter to document tumor-cell kill and neurologic safety in the delicate brainstetin region (the posterior fossa) using PDT with LED-light and Lu-tex.

\section{Lu-Tex In Vitro Experiments}

Red light for PDT in vitto was produced by a Q-beam photosynthesis lamp (Figure 2) ( Ouanam Devices, Ine, Bameveld, WI, USA). The emitting surface measured 6xlo cra and contained 198 light enjtting diodes, The LED chips are on the suface of a ceramie gink with a ventilator to prevent overbeating lo order to deliver LED light in wivo, an LED probe was constructed (Figure 2). The LED probe consists of a 10 cri hollow steel tube that has at its tip the LED chips anranged in a cylinder. The core of the tube contains three channels. One channel contains insulated wires 


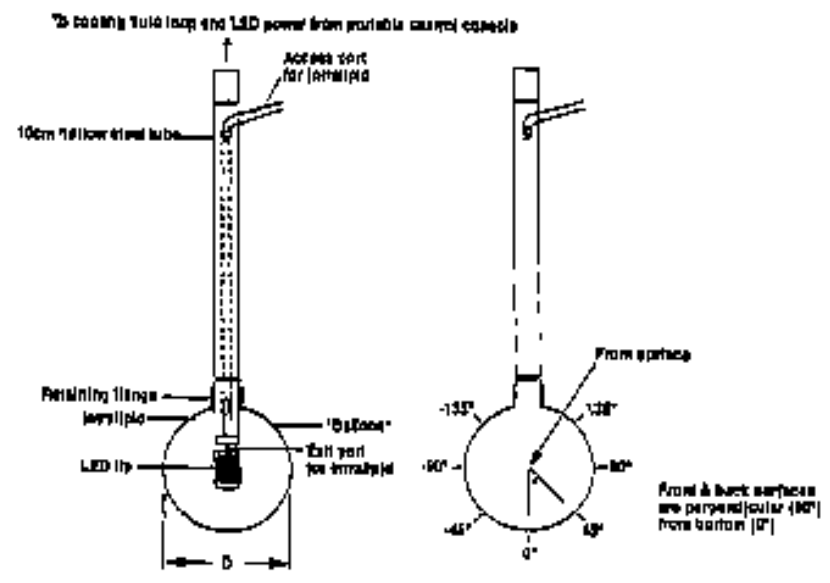

FIGLRE 2. The LED Balloon Applicedror in a Igehenatic Overview.

which provide electricticy for the LED tip. A second changel eontains sterile water which acts as a cooling flujid when circulated arotud the tip. The thid chandel provides access for the 0.1 persent intralipid fluid uned to inflare the balloon at the rip of the probe. The pirnp for the cooling fluid and the power supply are in a portable base unit. Power cutput of the LED dip is adjusted wia a potentioneter on the base unit which controls current flow. The temperanure of the tip was continuously mogitored and was not allowed io exeeted $35^{\circ} \mathrm{C}$ ar any time during the expeliment. The balloon of the LED probe was inflated with a 0.1 percent intralipid solution. Balloon dianterer ranged forn $2 \mathrm{~cm}$ to $5 \mathrm{~cm}$. The tip of the LED probe was placed in the center of the bajloon. In this ennigurarion, the balloon is known ro searter light uniformly, with light irfadiation: varying by no more than twenty pertent of the average when meastred at any point on the balloon's surface. The total power output was 1.0 wat at the tip and was kept constant.

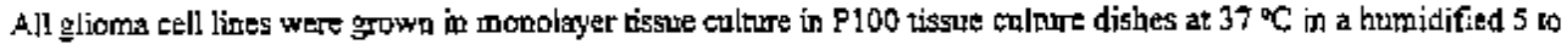
$10 \% \mathrm{CO}_{2}$ atmosphere, as previously described Cultures were harvested by gendy dislodging the cells from their substratum with a Pasteur pipette for in vitro sgsay. Gliona cells were then plated in 1.6 cm wells of a 24 plate. Following 24 hours of attachurent Lu-Tex was added in increasing concentrations form 0.0 to 30 uM. All experiments were done in tiplets, Control eells rectived an equal volume but no Lu-Tex. The Ltr-Tex concentration used did not cause any dark toxiciry. After 3 hours incubation in the dark the cells were exposed to the light from the LFo lamp. The energy density was $1.8 \mathrm{~J} / \mathrm{cm}$ : Approtinately 24 hours ater completion of LED teannen cell viability was assessed by measuring uptike for $3 \mathrm{H}$-Ihymidine in DNA. After extraction the radioacdivity was counted.

\section{Lu-Tex in Viva Experiments}

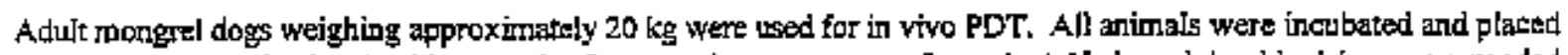
under general anesthesia. A wide posterior rossa craniectomy was performed. A $Y$-shaped dural incision was extended to expose the cerebellurb, lower brainstem and upper esvical spinal cord (Schumidt, 1994; Schmidt, 1996; Whelan, 1995). The LED balloon afplicator with a disneter of $2 \mathrm{~cm}$ was placed into the postorior fossa en the brainsten.. All canines received Lu-Tex 3 to 5 hours prior to light exposure ( except light only controls) in increasing doses srarting a 0.75 mg/kg accorting to the Fibonacci dose escalation scale (Collins, 1986; Goldsmith, 1975). The maximum toletazed dose (MTD) was defined as the dose given to the group of eanines that preceded the group with $50 \%$ neuro toxicicy. The i.ED was adjusted to deljver light speetran with a peak wavelength of $732 \mathrm{sm}$ and bandwidth of 25 am. The structural details of the porobe and spectral anabsis were published prevously (Sctumidt, 1996). 


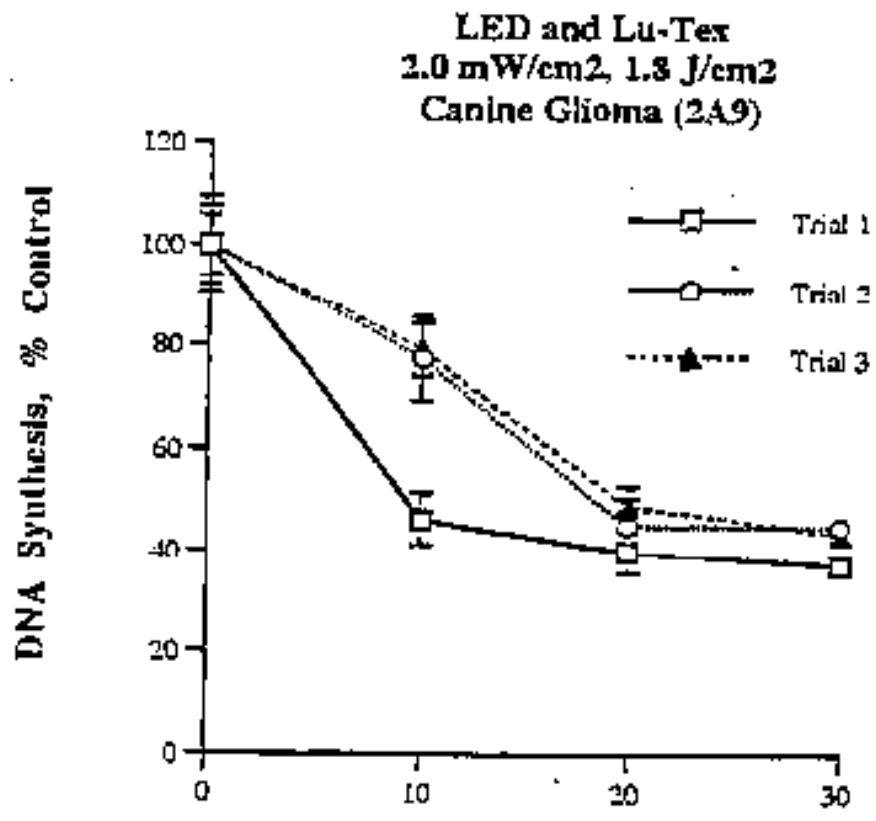

FIGURE 3. Lu-Tex Doste (ulM) 24 hr. InRabation.

\section{Results}

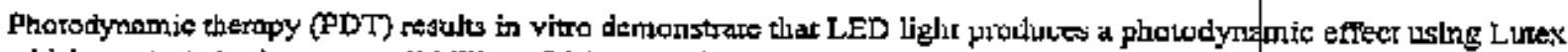
which resulte in brain tumor cell killing. PDT restlts in wivo further demonstate that LED light at I00 J/cm" is safe with a maximum tolable dose (MTD) of Lutex of $1.6 \mathrm{mg} / \mathrm{kg}$ for treatment in the deligente brainstem regions.

\section{Photodynamic Therapy for Glioma Cells in Vitro}

The grapht in Figure 3 shows that Lu-Tex sensirized ghema cells are signifiemtly inhibited when exposed to LED light. Light only and Lu-Tex only controls dertonstrated no signifficant growth inhibition on glioma cells (Fjgure 3 ).

\section{Photodynamic Therapy in Canine Model}

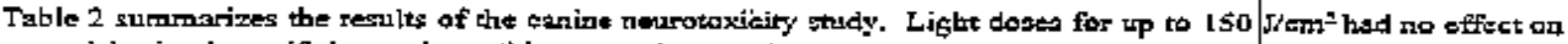
normal brain tissue if the canines did not receive any Lu-Tex, Several arimals in the Lu-Tex escalarion study experienced mild post operative ataxia that resolved witin 48 hours. One animal died 48 hours after PDT with 1.0 ang/kg and $100 \mathrm{~J} / \mathrm{Cum}^{2}$ lipht. Autopsy revealed a large extradural blood clot compressing the braitsiter that was most likely ravmatic. Other animals at the same dose showed no permabent defieits. The Lu-Tex dose was then esealated progressively at a constant light dose of $100 \mathrm{~J} / \mathrm{om}^{2}$. At $2.0 \mathrm{mg} / \mathrm{kg} \mathrm{Lu}-\mathrm{Tex}$ all animals expired taltriediately after PDT ( $<24 \mathrm{~h}$ ) secondary to respiramory difficulties. In addition, they showed severe signs of quadroparesis, ataxia and swallowing difiticulties, The dose was then decreased to $1.6 \mathrm{mg} / \mathrm{kg}$. All animais experiencefl mild transient ataxia except for one canine which expired 48 hours after suretery' Antopsy revealed a gomoal brain strueture unfike the animigis at $2.0 \mathrm{mg} / \mathrm{kg}$. We subsequently repeated the sane dose of Lu-Tex and Light. These additional four canines had no penament deficits. Thus, the MTD accordinn to our prococol is $6.6 \mathrm{mg} / \mathrm{kg}$ and $100 \mathrm{~J} / \mathrm{man}$ (Table 2). 
TABLE 2. Summary of Canio Photodyatnic Therapy Study.

\begin{tabular}{|c|c|c|c|c|}
\hline $\begin{array}{l}\text { Lu-Tex Dost } \\
\text { (mu/kg) }\end{array}$ & $\begin{array}{c}\text { Conine } \\
\mathrm{N}=21\end{array}$ & $\begin{array}{c}\text { Lught Dose } \\
\left(\mathrm{IJcm}^{2}\right)\end{array}$ & Clinical Toxicity & Autopsy \\
\hline 0.5 to 075 & 6 & $=150$ & none & nonzal \\
\hline 1.00 to 1.25 & 6 & 100 & 1 mortality & Certbeflut hemorage \\
\hline 1.6 & 6 & 100 & 1 morrality & Normel braig \\
\hline 2,0 & 3 & 100 & 3 mortalitites & Severe braingtem edth \\
\hline
\end{tabular}

\section{Discussion}

Lutetiar texaphyrin (Lu-Tex) is a pure, hydrophilic photosensitizar that is synthesized by insering a lutetiurn meta) into the center of ing shaped, planar porphyin molecule called texaphyrin. The mbehanism by which porphyrins including texaphyrins preferentially accumulate in cancer cells is not fully elucidated. Tuntor langlizing properties of texaphytins are related to high metabolism in tancer cells similar to other porpbyrins. Texaphyrits can be engineetred with different central metals which influences the biochemical reaction they mediate while netaining their tumor localizimg properties. Gadolinitur texaphyrin has been waluated as a MRI contrast agent, radiationsensitizer and

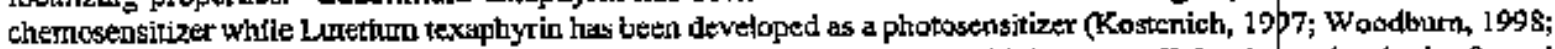
Woodbur11, 1996; Youne, 1996; Young, 1994; Young, 1996). Lu-Tex exbibits srong light absorption in the far red spectrum (730 to $770 \mathrm{~mm}$, peak $732 \mathrm{~mm}$ ) where tissue light penetration is at least deubled compared to $630 \mathrm{rm}$ (Eggert, 1994).

The therapeuric efilicacy for PDT of brain thmors has been demonstrated in several clinical and experimental studies (Kaye, 1988; Kaye, 1987; Muller, 1987; Muller, 1990; Muller, 1995; Mutller, 1996). Most series for human recurrent

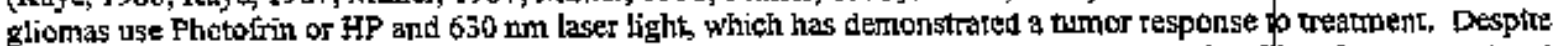
that stecess, local recumenoe remains the most eommon cause of treatment failure after PDT just like after comventiontal treatrinent (Kostron, 1996). Most investigators think that this is most likely secondary to infiloralive tumor cell in the brain adjacent to turfor (BAT) (Powers, 1991). Surdies have shown that photosensitizer is taken up in the BAT and that increasing the light dose which increases tissue light fluence demonstrates a greater therapeutid sutecess (Hill, 1990: Muller, 1995). Another way to inerease the light dose for deeper tissues is to inerease the wavelength of the incident light into the far red spectrum. Unfortunately, Fhotofrin and HP absor light poorly beyond $630 \mathrm{~nm}$. New photosensitizers like BPD and Lu-Tex absorb light at longer wavelength (Aveline, 1994; Y'oung, 1996).

Yortal brain tissue toxicity can oocur in PDT of brain num ors. Several studies indicate that at high photosensitizer dose Putotuin, bematoporphyrin, and even second generation photosensitizers like Benzopophyrin detivative, can sensitize normal brain tissue to photodynamic effect (Muller, 1987; Schnidt, 1994; Schrnidt, 1996; Whelan, 1993). This study indicates that Lu-Tex can cause nomal brain tissue Aamage at high doses $(\$ 2.0 \mathrm{mg} / \mathrm{kg})$. With careful drug and light

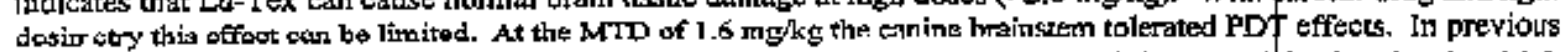
studies using the same posterior fossa canine model we demonstrated that nomal tissue toxicity is related to high phowesensitizer toses rather than high light doses.

In addition to limited nomal tissue toxicity, Lu-Tex also demonstrated the abjlity to irhibit the growth of glioma cel[s in vito similar to other perphyriv başed photosensitizers. Lu-Tex has been ghown to be localized to metastatic brain tarnors in humans. Thus: Lu-tex with LED light have the potential to effectiveIy treat brain tumors. 


\section{CONCLUSION}

Lu-Tex aurbijed with an LED light soumec can potortially incrase the tharapeutic efficacy of PDT of brait tumors without increasing normal tissue toxicity. Longer wavelengths of light than previous]y practical were provided by LED technology. The development by NASA of new light sulrees and light delivery devices is of critical importauce tor inprowing photodynanic therapy.

\section{PART II - WOUND HEALING}

Improwed wound healing may have multiple applications which may benefit civilian medical ane, military situations and long-tem space flight.

In space, wounds may heal differently than here on earth. Laser light has shown some benefrt for wound healing but has lionited surface area and wave lenght. Light-emitting diodes, developed by NASA, offer the potential for dramaxie improvernent in wound healing over lasters far fume space flight, eivilian and military applieations.

Laser light and hyperbaric oxygen heve been widely acelaimed to speed wound healing in ischemic, hypoxic wounds. There bave bed few comparative studies done to document value over other methods sucb as meticulous surgical debridement, antibiotics, limited amputation, contact fasting, adjunctive pentoxifylfoe, wopical oxygen, topical growth factors, and careful attention to host factors such as diabetes control, nutrition, atc.

\section{Light Studies}

A category of lasers terned "soft" or "cold" lasers, provide low enorgy stimulation of tissues which tray result in increased cellular activity during wound healing (Mifler, 1993). This principal of laser biostimulation was introduced by the Russian' 3 ovtr twenty years ago and is applied primarily in dematolopy for skin wound healing. It has also been suggested that biostimulation by light nay be useful in other wound healing scenarios. Low-powered lasers were used to treat areas of skin and accelerate wound healine. Subsequently, cold lasers have been used to provide pain relief and perform non-surgical face lifts. In eastern europe, heliun neon-lasers with low power densities, were reported to stimulate slín graft healing in rabbits, regenerate burned skin in tats, and accelerate mucous motrobrare repair in the rongue in mice.

The proposed mechantsm of action of low-powered light iradiation was supposed to effect cellylar metabolic processes and improve rageneration potential (Gamaleya, 1977). There have heen many problems tryine to determitie what wavelengths of lipht are best. The ust of lasers bas been problematic because of limited wave-kength and beam physics (narow beam of woherent light). Studies have included different kinds of lasters, wave-lengths, time-exposures, energy settijugs, laboratory arimals and cell cypes (Meyers, 1990).

Wound bealing has three phases. First a substrate is laid down, then cells proliferate, then there is remodeling of tissue. The daca published so far suggests that laser biostimtiation produces its prinary cffect duripg the cell proliferation phasie. It is fell Llat injtochondria are rabeptive to monoehromis light and that these haser experimante have increased respitatory metabolism of certain cells (Meyers, 1990). Such: things as fibroblast proliferation, collagen synthesis, growth factor protuction, induding kersinocyte growth factor (KGF), transfoming growth factor (TGF) and plateletderived growth factor (PDGP), as well as mactophage stimulaticn, and grtater rate of extracellular matrix production have been reported.

Lasers produce unique light irrafiation differing from other light sources, but are limited in way elength capabilities and beard width for teehnical reasons. Previous experinents, however, using lasers have demongrated unique properties in biological systems. Scientisłs experimenting with low intensity laser's attempting to evaluate effeets on tissues and cell cultures have published articles about stimulating cell activily. Wavelengths have typically varied from $630-730$ $\mathrm{nm}$ but have been as high is $780 \mathrm{~nm}$. Four Joules $\mathrm{em}^{2}$ of total light dose, with powers in the milliwatt range bave 
trpieally been provided. FibrobTast proliferation, atachment and synthesis of collagen and procollagen have all been produced.

It was reported in torlite literature that heliun neon laser light at $633 \mathrm{~nm}$ was optirtal for wound healing (Basford, 1986) using 1 m $W$ exposures and greater to provide 4 Joulesim ${ }^{7}$ energy dersity, Later sablies looking at in vitro skin fibroblast stimulation denonstrated thar consecutive exposirts of $660 \mathrm{~nm}$ and $780 \mathrm{rm}$ lastr light at 24 hour irmtervals. incteased collagen production fourfold compered with untreated culthres (Lubart, 1992, 1997; Y4, 1997). Beavoit (1994, 1995) demonstrated that witochondria provide $50 \%$ of the tissthe aborption coefficient and $100 \%$ of the light scattering at 780 nin due to cytochome af3, cytochume oxidase and other mitochondrials chromophores. Fibroblasts irraflared ar $660 \mathrm{~mm}$ with $2.16 \mathrm{~J} / \mathrm{cm} 2$ increased fibmblast gowth factor synthesis and fitoroblast proliferation (Yu, 1997).

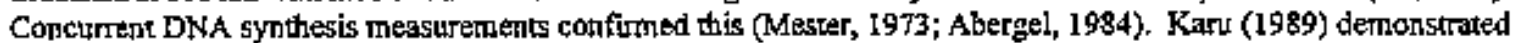

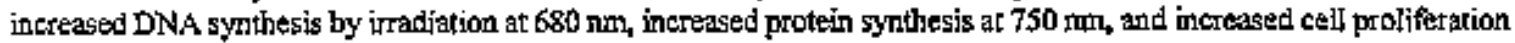
at $890 \mathrm{~nm}$, which was 10 times more effective than other near-infrared wavelengtos, requiring only 1 Jicm2.. Laser scimulation of collagen synthesis measured by incorpomtion of radioactive am ino acids was demonstrated ar 693 nnt with sinilar results. More recently, the work of Dr. Norruan Salansky ${ }^{4}$ has indicated that grouth factor production and collagen syathesis may be improved at warelengths of 660 - $680 \mathrm{~nm}$ and stimulation of new smell blood vestel growth was produced at $880 \mathrm{~mm}$ wavelength. Such stodien have been livited by the eonstraints of laser technology, but LED's affer itrptowed power and area of distribution at ionger wavelengths.

The mechanism of action is not fully understod, but presible explanations include stimulation of ascorbie acid uptake by cells, stimulation of photo receptors in the fnitontumdia respiratory chain, changes in ceIlulat ATP or cAMP levels and cell membrane stabilization.

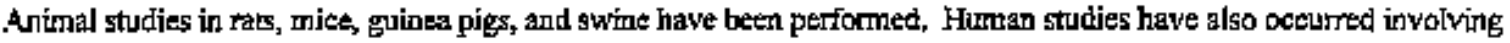
areater amounts of epithelialization for wound closure (Mccaughan, 1985). A nurnber of other human studies have denonstared that low energy laser systems pronote tissue healing (Lyons, 1987; Kana, 1991; Mester, 1982; Kovacs, 1982; AbergeI, 1987; Cumnings, $1985 ;$ Huter, 1984; Karu, 1989; Bravermar, 1989; Kowacs, 1974; Saimj, 1982; Mester, 1985; Kahn, 1984; Chlebarov, 1988; S1g!te, 1990). Other ștudies trave demonstrated difficulties with human healizg using laser systens. Wavelength and waveforn of the optical soures, power, output and three dirrengional

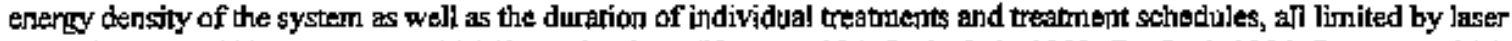
tetinology, wotld be inproved with LED technology (Hunter, 1984; Surinchak, 1985; Bafford, 1986; Bnmner, 1986; Lundeberg, 199 I; Sentoianni, 1984; Gogia, 1992; Kane, 1982; Van Brengel, 1992; Braverman, 1989; Megter, 1965; Kroetlinger, 1980; Longo, 1987) lo a study of nine patients with l2 leg ulcers, the combination of two light sources

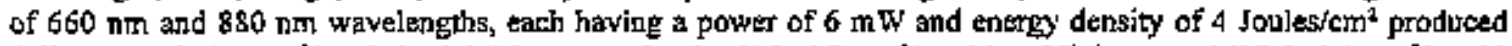

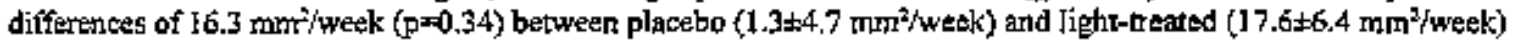
groups, during the first 4 weeks of low energy photon therapy, but the assistance of another treatment modality to maintin the original race of healing is required.

It is believed that our experimengl design will address these issues. We plan to use LED's emitting light at 680 nm, 730 III, and 380 nin to stimulare growth factor production, collagen synthesis and micowascular angiogenesis in healing wound tjssut. Furthtrinote, LED-treament will be combined with hyperbaric oxygen and growth factor therapy.

\section{Hyperbaric Studies}

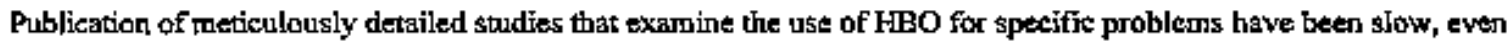
though FFO therapy has besn in clinical use since 1943. Both the dificulty end cost of developing controlled, doublebind, randomized trials have impeded the soientifie standards of medicine today, despite a prostession of studies of the diabetic foot. Devis et al believed that appropriate historic controls for dernonstrating the offeacy of hyperbaric therapy caluh be represented by patients with chronic wemds that were unrespotsive to standard technígues (Davis, 1988). No prospective controiled trial has been used for the surgical technique for monagement of the diabetic foot problem (Dawis, 1988; Davis, 1991; Cienci, 1993). And as stated by Feldmeier et al no doubIe-blind studies sxist in the encire field of radiation therapy (Feldmeipr, 1996). Such strdies are imposstble for ethical and techrical reasons. 
The nacessity and expense of performing double-blind byperbaric studies has long beten recogtized. Two commonly used sudy endpoints in typerbaric soudies are the autcome based Jeduction of amputation rates, and "healing", defined as the lack of netd for amprutation above the ankle. Existing surdits do not include an absolute neasure of healing such as: 11Ledsuremer. of grantulation tiague.

The medical practice paradox that compensates for limb ampuration rather than limb salyage is frequently deseribed by Cianci (1988) and Cianci (1994). The managenent of chronic wounds, especially in an aging sociery, is a growing problem that calls for novel techniques based on the wound microenvironment. Two approaches that specifically address the identified pathoplyysiologic processes are byperbaric oxygen therapy and growth facter research. Hyperbaric oxygen therapy, however, is the most specific teatment for the identified abnormality.

Davies (1987) described a retrospetive review of the group's experience. Their findings demgnstrated a $70 \%$ suceess rate of healing and a $30 \%$ failure. Patients who did not require amputation above the ankIe were classified as successful. Patients with large vessel disease were often categorized as failures due to their linitations of distal perfusion.

In addition, several other retrospective aticles have been publishod (Hart, 1979; Pedesini, 1984; Perrins, 1986; Oriani, 1992) but the data reported by Stone (1995) and Stone and Seott (1995) is the most provocative. Stone et al found that patientg who were referred for hyperbatic therapy showed more wounds per patient, greater upoud volumes, and had a greater percentage recommended for amputation. Even thougb the wounds mere more serions, the limb-salvage rate was greater in the hyperbarie treated group (72\% versus $53 \% ;$ pro.002).

The data collected by Stone and Scott measured wound volumes by categorizing patients int three groups: standard care, standard care with adjuvant hyperbaric therapy, and both combined with growth faetofs. Standerd care (60\% healing) versus standard care with byperbane therapy (63\% healing) showat no significant difference in healing rates. However, the arerage wound volume in the hyperbaric-treated group $(2,750 \mathrm{~mm} 3 ; \mathrm{n}=38)$ was twice the size of the sandart care group $(1,144 \mathrm{~mm} 3$; $n=250$ ). The Ereatest healing rat: was demonstrated by the group that was treated with the combination of standard care, hypertaric therapy, and growth factors $(80 \% ; 2,414 \mathrm{~mm} 3 ; \mathrm{n}=49$ ). Like anirnal studies this data suggests a synergistic effect of combination therapy. Thus, we will combine LED near infrared light, hypertaric oxygen, and growth factors in our human treament protocol.

\section{Methods}

Fibroblast Studies:

DNA synthesis in cultured 3T3 fibroblasts was measured after incubation tis the presence and abpence of $4 \mathrm{~J} / \mathrm{cm} 2$ of LED light ax $6 R 0 \mathrm{~nm}, 730 \mathrm{~nm}$ and $880 \mathrm{~nm}$ using tritiated $(3 \mathrm{H})$ thyrridine incorporation. After $3-4$ bours in $0.01 \mathrm{mCi} / \mathrm{ml}$ (methyl 3H) thymidine (6.7 uCimole), cells were washed and assay stopped with $10 \%$ tichlorhacetic acid. Cells were dissolved with 0,2N sodium hydroxide, and tritius uptake counted in liquid scintillant using a scintillation coutnter.

\section{Animal Stadies;}

- 44 male Sprague-Dawley rats were wounded with a $35 \mathrm{~mm}$ full-thicksess skin excicion.

- Rats were divided into four groups whinh we treated as followe:

Group l-Controls, no treatment

Group 2-Experimental light treatment (ELT) only

Group 3-Hyperbaric oxygen treatment (HBOT) only

Grọup 4-ELT and HBOT

ELT consisted of geventten daily exposures to 4 Joules/cm2 each of 680 and $730 \mathrm{mat}$ light.

- HEOT consisted of geventeen daily exposurs to 2,4 atmospheres of pure oxyen for 90 minutes.

- Wounds scze was monitored by photography and analyzed by Slgriascan Fro softures.

- Would area was expressed as a percentape of original size; groups compared to by Student's T-test 


\section{Results}

Our in wivo wound healing expeniments demonstrared a therapeutic benefit of LED light plus hyperbaric oxygen therapy

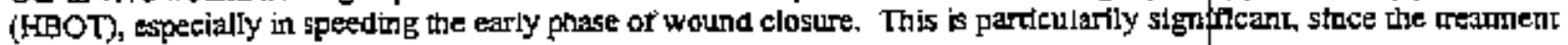
improved upon healing in a model using wounds in bealthy rass.

\section{Anima! Studies:}

Preliminary dan indicate thar Ell, decreases wound size 7, 12, and 17 days after wounding when used alone and 7 and 11 days after wounding when combined with FBOT (Figure 4) (Table 3).

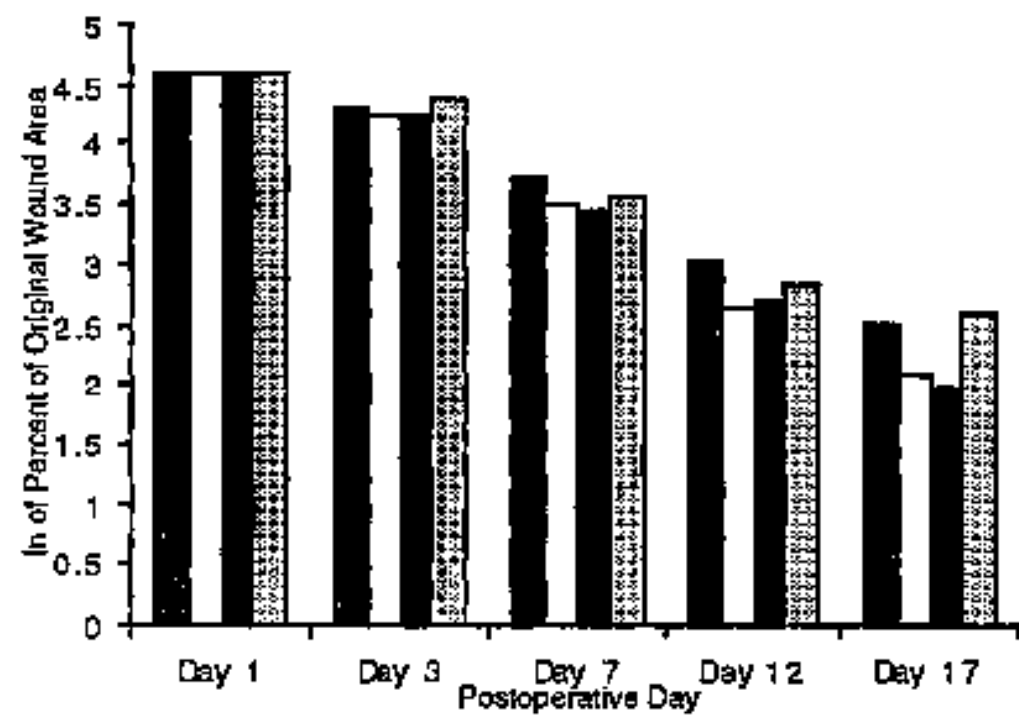

FIGURE 4, Reduetion in Wound Sizt in Experimental Controls and Trtared Rars.

TABLE 3. Reductan in Wound Size in Experimeptal Cintrois and Tremed Rat.

\begin{tabular}{|c|c|c|c|c|c|}
\hline & $\begin{array}{l}\text { Wound Area. } \\
\text { Perrent of } \\
\text { Drigingi Sirea }\end{array}$ & & & & \\
\hline Group & Day 1 & Day 3 & Dey 7 & Day 12 & Diy 17 \\
\hline Unthafed control & 100 & $73.5 \pm 7.9$ & $41.4 \pm 3.4$ & $20.4 \pm 3.8$ & $12.4 \pm 2.9$ \\
\hline ELT ondy & 100 & $697 \pm 5.7$ & $33.2 \pm 62$ & $14.1 \pm 1.7$ & $8.1 \div 20$ \\
\hline HEOT andy & $\mathrm{J} 00$ & $70.1 \pm 4.5$ & $31,4 \pm 3.5$ & $14.8 \pm 1.6$ & $72 \pm 1.6$ \\
\hline ELT and hot & 100 & $79.9=13.7$ & $34.7 \pm 5.5$ & $17.0 \pm 4.6$ & $13.4 \pm 5.4$ \\
\hline
\end{tabular}




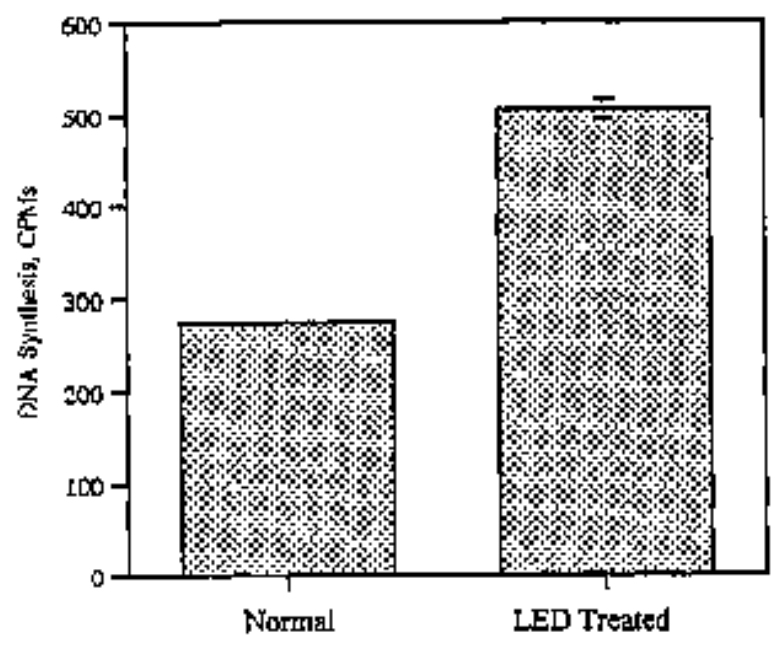

F1GURF 5, Inteaser DNA SYnthesia In Fbroblaste Treated With LED Light Compared With Nomal Control Exprestd as (3H) Thyridine Uprake In Counis Per Misute

Culaured fibroblast data supponts he animal data by demoustrating doubled DNA synthesis when cells were treated with LE.D light (Figure S). This is particularly inporant sinee fibroblasts are the major tell cype needed to grow and divide is healing wounds.

\section{Discussion}

As previously noted, prior studiss involving hasers bave demongtrated that light does hejp wround bealinis, but current applications of light therapy are Tisjint to the use of low power laser light. Dut to the nature of light physics and engineening constraints of laser design, the range of wavelengths attainable is lifirted. Due to the coherent beam of light urique to lasers, their abjity to easily treat large areas is also limited. NASA's development of light enitting diedes (LED) offers an alterpative soumce for light therapy that can be desigged to produce many wavelengths and in an array of varjed shape - thus enabling it to diect lighr over a large or 3-D surface. In this case study, the LEDs were desigoed to errit light at wavelengtht proven, in prior studies of lasser light, to speed wound healing. The LED's were manufactured in a square box array to provide uniform eneroy density to the subject rars.

Cutured fibroblast data demonstrated doubled DNA synthesis in the eeil type most proliferative in healing uounds. This provides trexrendous encouragement in support of animal studies leating to butsas trials. Data in rats agepes, The data from this initial group shows that there is a cole for LED therapy. The rats receiving LED therapy showed a significant increased wound healing when compared to controls. Additionally, this rate of healing was comparable to the rare resulting fros the established daily hyperbaric oxygen treatront (HBOT) of 2.4 ATA for 90 minutes. The current standard of care for problem wounds allows for the adjunctive therapy of HEOT in cases such as diabetic ulcers, graft. failures, radiation necrosis, and other ischemio wounds. However, the acesess of patients to a hyperbaric treatment center is not always avai]able, and many factors can make it diffieult for patients to underco bigh pressure teatments. Our initial data is promisim in that it offers the first evidence to a seeond adjunctive modality for problem wounds. While the coplabined tresmett of both LED and HEOT did increase wound healing when compared to controls, it did not offer synerpistic effects on bealing in tis intitial group. Additional studies with timger groups of rats, as well as the addition of $880 \mathrm{~nm}$ LED-light in combination with $680 \mathrm{nnh}$ and $730 \mathrm{~nm}$ LED's are eurrently undenway, and may offer insight into mechanisws for inproving synergy. Future human trials of LED and HBOT efficacy are also planned.

Wo anticipate that our continuted trials will consistently demonstrate the efficacy of LED therapy on wound healing. The ability to make LEDs of various wavelengths, their low power consumption, and ability to design the acnal LED array in warious shapes and sizes makes it ideal for an adjunctive therapy. It has unique application to military and space environments, where speed of healing, durability, esse of operation, and portability tre essential tactors. LED excels in these areas, presenting a possible treatment modality that may enable the success of a mission compromisted by an injury. 


\section{ACKNOWLEDGEMENTS}

We wish to thank Karen Zeqiri for assistence in manuscript preparation. The LED arays were provided by Quartum Devices, Ine., Bameveld, WT. We also greatfully acknowledge the Deparment of Defenst. Air Force Material Command, Armstrong Laberatories, Davis Hyperbaric Laboratory, Brooks Air Foroe Base, TX for providing the byperbarie chamber used in this research. This work was supported by NASA-SBIR fNASW-499 National Aeronautic5 and Space Adninistration NAS8-97277, Children's Hospital Foundation, the MACC Fund and quantum Devices, Inc.

\section{REFERENCES}

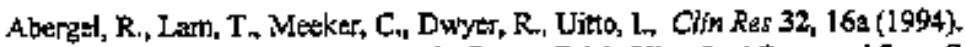

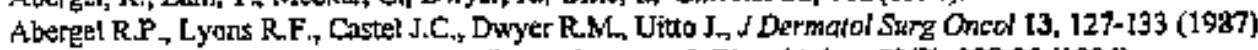

Aveline $B_{r,}$ Hasan T., Redmond R. W, Photodhenistry \& Photobiology 59(3), 328-35 (1994).

Basford, J., Mayo Clin Proc 6I, 671-675 (1986).

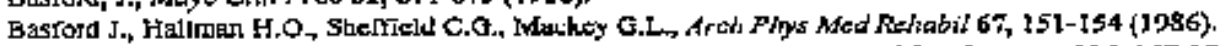

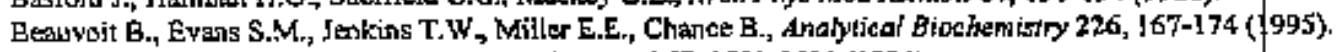

Beauvoit B., Kitai T., Chance B., Biophypical voumol 67, 2501-2510 (1994).

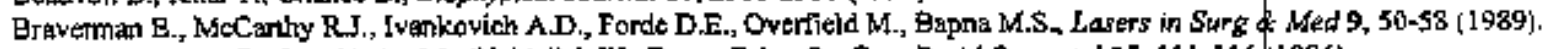

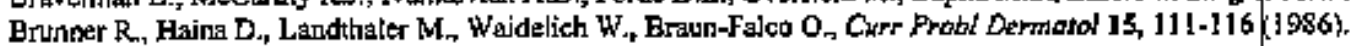

Chlebarow S., Wed Foour 3, 48-49 (1988).

Cianc: $\mathrm{F}_{\text {. }}$ JAPMA B4, 448 [1994).

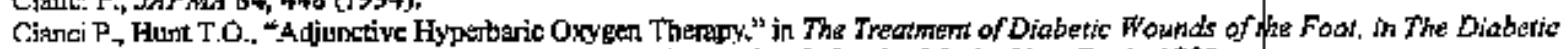
Foot, edited by ME. Levin, L.W. O'NeAl, J.H. Bowke,Si Louis, Mosby Year Book, 1993.

Cianci P., Petrone G., Deates S,W., et al, $J$ Hpperb Med 3, 127 (1988).

Collins J. M. Zaharko D.S., Dedrick R.L, Chabner B.A., Cancer Treamert Reports 70(1), 73-80 (1986).

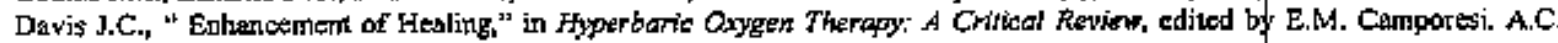
Barker,Bethesda, MD, Undersed and Hyperbaric Modical Soctety, $199 \mathrm{l}$.

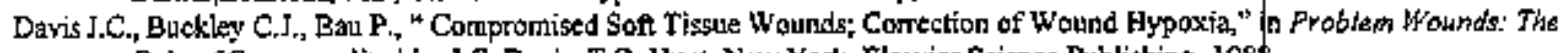

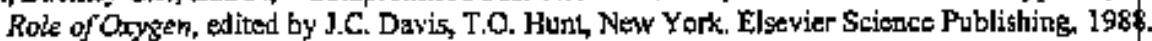

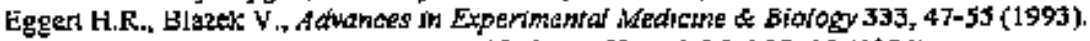

Feldreicr J.J., Court w.S., Matos L,A., Undersea Hyperb Mad 23, 10 ( [596).

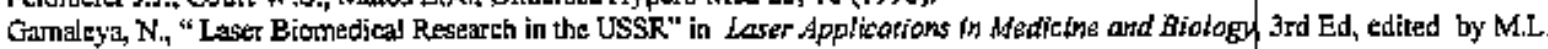
Walbarsht, New York, Leddon, Plenut Pross, 1977, Pp. 1 14-126.

Gopia P.P. Marquez R.R., Orteony Wourd Mgmat 38, 38-4L (1992).

Goldsmith M.A, Slavik M. Carter S.K. Concer Regepreh 35(5), 1354-64 (1975).

Haina D., Buntiner R, Landthaler ML, ol al, Lager Boste Biomed Rer 22, 1-3 (19:2).

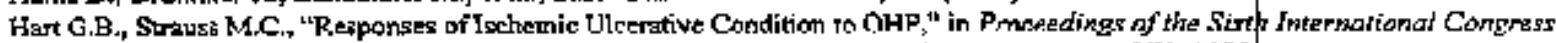
on Syperbaric Medieine, edited by G Smith, Aberdeen University Press, Aberden, UK, 1979

Henderson B. W., Doughery T.J., Phomochemity of Photobiglogy 55(1), 145-57 (1992).

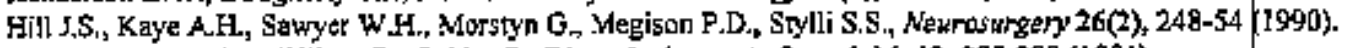

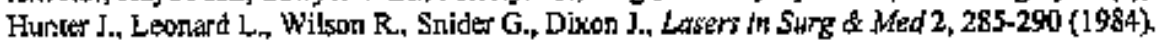

Kahn J., J Ortho Sparis Phys Thet 3, 203-204 (1984).

Kana J.S., Hutschemseirer G. Haina D., Waidelich W., Areh Surg 116, 293-295 (1981).

Kar T foth Phprios 56, 691-704 (1989).

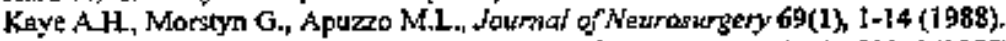

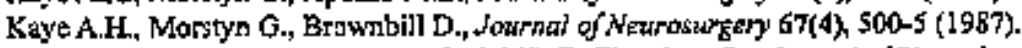

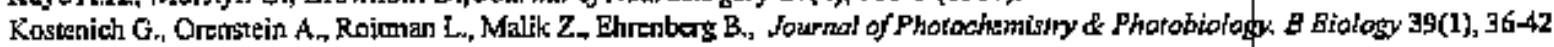
(1997).

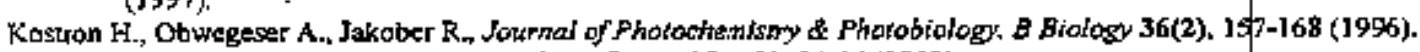

Kovacs L., Varge L., Palyi E., et al "Laser Baric Romed Res 12, 14-16 (1982).

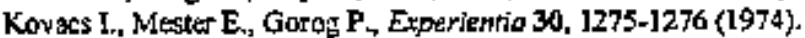

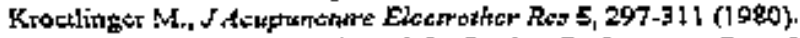

Longo L. Evangelista S. Tinacxi G., Sesti AG., Lavers in Sarg \& Med 7, 444-447 (1987).

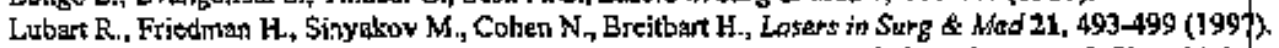

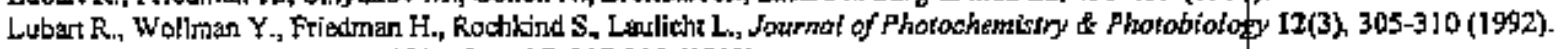

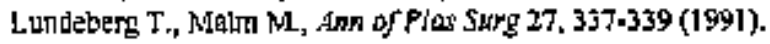




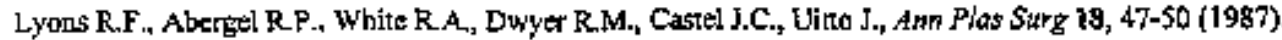

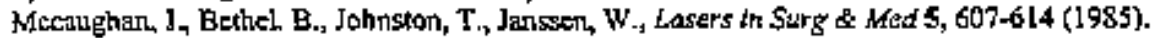

Mester, E., Jaszsagi-lNagi, E. The effect of laser mdjation on wound healing and oollagen synthesis. Studia Btophysica 35, 227-250 (1973).

Wegtar E. Meste A.F Merter A, Lasers in Surg \& Wed 5, 31-39 (1585).

Mester E, Toth W., Mester A, Laser Basic Biomed Res 22, 4-7 (1982).

Mevers, A, Amer J Swrg 122, 532-535 (2990).

Willer, M., Theilade, E., Jersen, S., JADA 124, 32-35 (1993).

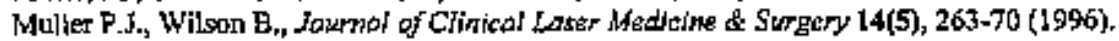

Muller P.I., Wilson B.C., Fhorochemitry \& Phorobiology 46(S), 929-35 (1987),

Muller P.J., Whilson B.C., Camotion Jour wi of Newrological Stieneas 17(2). I93-8 (1990)

Muller P.J., Wilgon B.C. Seminars in surgiod Oncology 11 (5), 346-54 (1955).

Grienj G., Michasel Mi, Meassa D., el al , J Hyperborke Hed 7, 213 (1992).

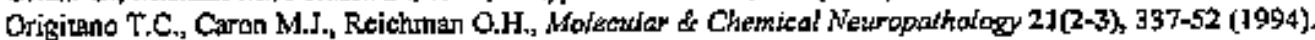

Pedesini G., Orimi G, Barmini C., el al, "Hyperbarie Onygen Therapy in the Treatment of Diabetic Vaseulopathies," in Froededings

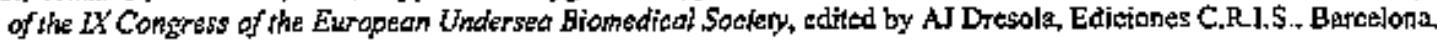
Spoin. 1954.

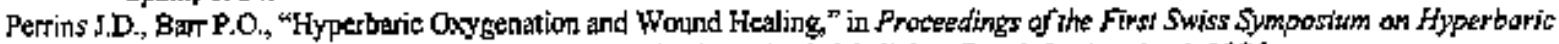

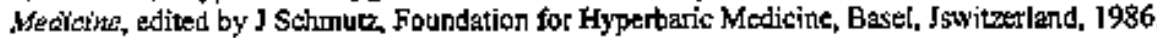

Popovie E.4., Kaye A.H., Hill 1.5., Seminars in Surgical Oncologe 11 (5), 335-45 (1995).

Powers S.K., Cush S.S., Whalstad D.L. Kwoek L., Neuroswrery 295), 688-95 (1991).

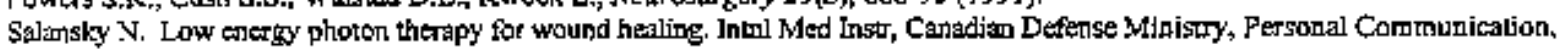
(I998).

Sentoiandi F., Monfrecola G., Martellotta D., Ayalka F, Photodarmalology 1, 245-249 (1984).

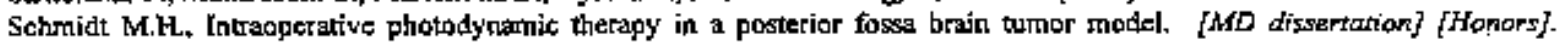

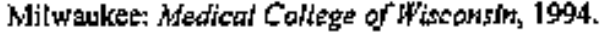

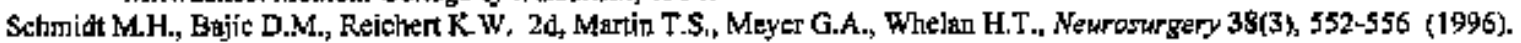

Stone I.A, Scott R.G., Undersed Biomed Res. Abstract 22, 78 (1995).

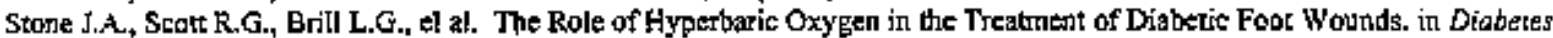

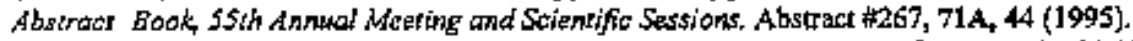

Sugue .M.E., Cardan J., Leen E.'., Feeley T.M., Noore D.J., Shanik G.D., Ann Vare Surg 4, J 79-181 (1990).

Surinchak J.S., Alago M.L., Bellany RF., Stuck B.E., Belkin M, Loserg in Surg of Med 2, 267-274 (1583).

Var Breugel $\mathrm{H}_{3}$, Bar P., Larers in Surg ok Wed 12, 528-537 (1992).

Whelä H.T., Schmidt MH, Segura A.D. McAulitfe T.L., Bajie D,M , Murray K.J., Mauldor J.E., Strother D.R., Thomas J.P.. Meyer G.A., Jourhal of Newrostrgerp 79(4), 562-8 (1993).

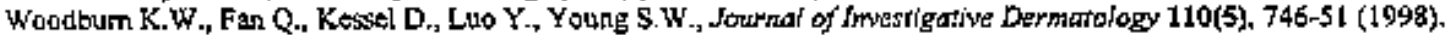

Woodbum K.W., Fan Q., Kescel D., Wright M., Mody T.D., Hemmi G., Magda D., Seggler J.L., Dow W.C., Willer R.A.n Young

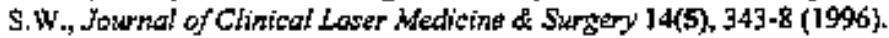

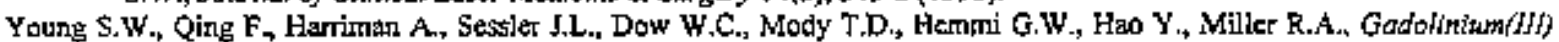
texaphyrim a tumor selective radiation sensitizer that is dekedidble by MRJ. PToceedings of the National Academy of Sejences of the Linited States of Arotrica $193(13), 1996$. pp. 6610-6615.

Yocne S.W., Sidhu M.K. Qing F, Mullet H.H., Neuder M., Zanasis G., Mody T.D., Hemmi G., Dow W., Mutch J D., et al.. inverigarive Radiolosy 29(3), 330-8 (1994).

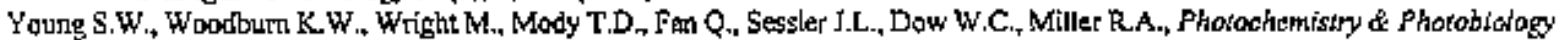
63(6), 892-7 (1996).

Yu w. Naim J.O., Lan zafame R.J., Phorophaming \& Pholoblology 59, 167-1 70 (1997). 